\title{
POTENTIALLY PATHOGENIC YEASTS FROM SOIL OF CHILDREN'S RECREATIONAL AREAS IN THE CITY OF ŁÓDŹ (POLAND)
}

ANNA WÓJCIK, PIOTR KURNATOWSKI, and JOANNA BŁASZKOWSKA

\author{
Medical University of Lodz, Łódź, Poland \\ Department of Biology and Medical Parasitology
}

\begin{abstract}
Objectives: Yeasts may become potential human and animal pathogens, particularly for individuals with a depressed immune system. Their presence in the environment, especially in soil, may favour their spread into human ontocenoses. Materials and Methods: Eighty-four soil samples obtained from 21 children's recreational sites in Łódź in autumn 2010 and spring 2011 were evaluated. The yeasts were isolated by classical microbiological methods and identified on the basis of morphological and biochemical features. Results: The fungi were found in $73.8 \%$ and in $69.0 \%$ of the examined samples collected in autumn and spring, respectively. Among 97 isolates of yeasts, the species potentially pathogenic to humans and animals were Candida colliculosa, C. guilliermondii, C. humicola, C. inconspicua, C. lambica, C. lusitaniae, C. pelliculosa, C. tropicalis, Cryptococcus albidus, C. laurentii, C. neoformans, C. terreus, Kloeckera japonica, Geotrichum candidum, G. penicillatum, Rhodotorula mucilaginosa, R. glutinis, Saccharomyces cerevisiae, Sporobolomyces salmonicolor and Trichosporon cutaneum. The most frequently isolated fungi included the genus Cryptococcus (38 isolates) and two species: Rhodotorula glutinis (15), Trichosporon cutaneum (14). C. neoformans, an etiological factor of cryptococcal meningitis, was present in the sandpits of 3 kindergartens. The Candida species were identified from park playgrounds and school sports fields mainly in autumn 2010 (14 isolates), in spring 2011 - only 1 isolate. The concentration of fungal species in particular samples varied considerably, but in the majority of samples, fungi were present at concentration of up to $1 \times 10^{2} \mathrm{CFU} / 1 \mathrm{~g}$ of soil. Conclusions: Yeasts were present in the soil of parks, schools and kindergarten recreational areas; the fact may pose a health risk to humans, especially to children, and this type of biological pollution should be regarded as a potential public health concern.
\end{abstract}

Key words:

Pathogenic fungi, Yeasts, Soil, Children's recreational areas

\section{INTRODUCTION}

Soil, being a very heterogeneous habitat, contains a great diversity of microorganisms. The fungi found in the soil play an important role in the ecosystem by forming and maintaining soil structure [1]. Yeasts classified as Ascomycota or Basidiomycota may be still present in soil or may be introduced into it from the organisms living inside or over the soil. The species composition of different soil-localities is highly heterogeneous and the quantities of fungi range from hundreds to millions of cells per gram of soil. Up to 130 species of yeast fungi have been found in soils worldwide [2,3]. The diversity patterns and abundance of yeast fungi depend on abiotic and biotic factors present in the soil, such as organic and inorganic chemical compounds and moisture, as well as other organisms living above and in the soil. Nevertheless, the relationship

The work was supported by the Ministry of Sciences and Higher Education of Poland - project No. 0065/B/P01/2010/39. Manager of project: prof. Piotr Kurnatowski, MD. Received: January 21, 2013. Accepted: June 6, 2013.

Corresponding author: A. Wójcik, Department of Biology and Medical Parasitology, Medical University of Lodz, Pl. Hallera 1, 90-647 Łódź, Poland (e-mail: anna.wojcik@umed.lodz.pl). 
between fungi development and the presence and concentration of the various environmental factors quoted above still requires investigation [2,4-6].

Fungi may become potential human and animal pathogens, especially for immunocompromised individuals. Their presence in soil may favour their spread into human ontocenosis; however, transmission of the pathogens from soil to the human organism has not been directly demonstrated. Populations of children, common users of sandpits, school sports fields and park playgrounds, are particularly at risk of being infected. In the available literature, a paucity of information exists regarding soil yeasts from recreational areas intensely used by humans, especially children $[7,8]$. The aim of the present study was to evaluate the quantitative and qualitative profiles of yeast fungi in the soil of recreational areas for children in selected districts of Łódź, Poland.

\section{MATERIALS AND METHODS}

\section{Study area}

Łódź is the third-largest city in Poland, located in the central part of the country, with about 737100 inhabitants (in 2010). Poland belongs to the temperate climatic zone with four distinct seasons. Łódź $\left(51^{\circ} 77^{\prime} \mathrm{N}, 19^{\circ} 46^{\prime} \mathrm{E}\right)$ is characterized by a mean annual air temperature and relative air humidity of $7.5^{\circ} \mathrm{C}$ and $80 \%$, respectively.

The surveys were carried out in selected locations of the city, in two seasons: October-November 2010 and April-May 2011. The soil and sand samples were collected from 21 localities in 2 districts of Łódź (Widzew and Śródmieście): 7 children's playgrounds from public parks or recreational places open for general use, 6 sandpits situated in school or kindergarten areas and 8 sites around various school sports fields. The playgrounds were situated both in large (Poniatowski and Piłsudski) parks, over 40 ha each, and smaller public recreational areas (Sienkiewicz and Staromiejski, Stawy Jana and Arturówek parks), covering an area of 5-40 ha each. All parks were unfenced, with free access.

All examined children's playgrounds were located close to developed (built-up) areas, such as housing estates, residential districts and family houses. Four of the seven playgrounds were not protected from the approach of domestic and stray animals, but the remaining three were enclosed by low fences not exceeding $1 \mathrm{~m}$ in height with a $1 \mathrm{~m}$-wide gate. All examined sandpits were situated within school or kindergarten areas which were securely fenced; there was no access for either domestic or stray animals. Five of the nine examined school sports fields were partially fenced, usually by only one fence located at the side facing the street; while the remaining four fields were unfenced. According to our observations, domestic dogs had ample access to all examined sports field areas, as those sites were favoured by dog walkers. Of note, also birds, especially pigeons, were also present on all examined sites.

\section{Collection of soil samples}

A total of 84 samples were collected during autumn 2010 (October-November) and spring 2011 (April-May) from the same 21 localities. All of the thirty-two soil samples taken from areas around school sports fields were obtained from a $10 \mathrm{~m}^{2}$ territory at 9 various points ( 9 subsamples), while for the sandpits and playgrounds, each of the 52 sand samples were collected from an area of about $5 \mathrm{~m}^{2}$ at 6 various points (6 subsamples). The subsamples were combined into one composite sample of about $300 \mathrm{~g}$. Samples of soil or sand were collected both from the $0-3 \mathrm{~cm}$ superficial layer at the surface and at a depth of about $15 \mathrm{~cm}$ from each examined site. Each soil and sand sample was placed separately into a sterile plastic bag, labelled by number and description and stored at $4^{\circ} \mathrm{C}$.

\section{Isolation and identification of the fungi}

From each soil or sand sample, two subsamples of $1 \mathrm{~g}$ and $0.5 \mathrm{~g}$ were suspended, each in $10 \mathrm{~cm}^{3}$ of sterile water, 
left at room temperature for about $10 \mathrm{~min}$, then shaken manually for $1 \mathrm{~min}$. After about $10 \mathrm{~min}, 1 \mathrm{~cm}^{3}$ of the supernatant was spread onto plates with sterile Dichloran Rose Bengal Chloramphenicol (DRBC) Agar (Merck) and the cultures were incubated first at a temperature of $25^{\circ} \mathrm{C}$ for $48 \mathrm{~h}$, then at room temperature for one week, with daily observations. Yeast colonies grown in the media were counted, checked under microscope, and transferred onto a Sabouraud Dextrose Agar to obtain the axenic cultural growth. Mycological identification was based on both macroscopic and microscopic morphological characteristics, as well as biochemical features [6,7]. The presence of carbohydrate fermentation and the ability to assimilate carbohydrates were identified with API 20C AUX tests (bioMérieux), and the ability for nitrogen compound assimilation was determined. Our study deals with yeast fungi classified as Ascomycota or Basidiomycota [10].

\section{Statistical methods}

The data was analysed using STATISTICA 6.0 software. The differences between groups were compared by the Chi-square test. If any of the frequencies were less than 5, Fisher's exact test was applied. Values of $p<0.05$ were considered significant.

\section{RESULTS}

In autumn 2010, the yeast fungi were found in $73.8 \%$ of investigated soil samples $(76.2 \%$ of samples collected from the depth $0-3 \mathrm{~cm}$ and $71.4 \%$ - from depth of about $15 \mathrm{~cm})$ and in spring 2011 - in $69.0 \%(57.1 \%$ and $76.2 \%$ - from the depth $0-3 \mathrm{~cm}$ and about $15 \mathrm{~cm}$, respectively) (Table 1). The differences between the frequencies of positive samples collected in both seasons, as well as from both soil layers, were statistically insignificant $(p>0.1)$. Soil specimens from partially fenced areas around school sports fields revealed a higher number of samples with yeast fungi in autumn than in spring, but the difference was insignificant $\left(\chi^{2}=3.232\right.$, $\mathrm{df}=1$, and $\mathrm{p}=0.072$ ).

By comparing the prevalence of fungi in soil samples from all investigated areas, a significantly higher number of positive results were found in children's playgrounds in parks than in school sports fields $\left(\chi^{2}=4.375\right.$, $\mathrm{df}=1$, and $\mathrm{p}=0.0168)$; in comparison, the difference was not so evident with sandpits $\left(\chi^{2}=3.823\right.$, df $=1$, and $\left.p=0.0505\right)$. The total number of the organisms varied between samples, but they were mostly present in numbers up to $5 \times 10^{2}$ colony forming units (CFU) in one gram of soil (Table 1). In sandpits, the fungi were isolated in smaller numbers, up to $1 \times 10^{2} \mathrm{CFU} / \mathrm{g}$ of soil from both the superficial and deeper layers. Analysing autumn and spring samples, fewer isolated fungi were observed in both layers from the school sports field soils.

Mycological examination of soil samples led to the identification of 97 isolates from 20 species of yeast fungi, potentially pathogenic to humans and animals (Table 2). In autumn 2010, the most often isolated were fungi of the genus Cryptococcus (23 isolates: 4 - C. albidus, 5 - C. laurentii, $10-C$. neoformans, $4-C$. terreus) and species: Rhodotorula glutinis (6 isolates) and Trichosporon cutaneum (7). However, in spring 2011, the most frequently R. glutinis (9 isolates) and T. cutaneum (7 isolates) were found. Cryptococcus species were also often detected (15 isolates: $3-$ C. albidus, $3-$ C. laurentii, $6-C$. neoformans, $3-C$. terreus). It should be underlined that fungi of the genus Candida were identified mainly in autumn 2010 (14 isolates); the only species found in spring 2011 was C. tropicalis (1 isolate). In one case, isolates of Kloeckera japonica (from sandpit, spring 2011), Sporobolomyces salmonicolor and Saccharomyces cerevisiae (both from park playgrounds, spring 2011) were identified.

The concentration of fungal species observed in particular samples varied widely (mean value: $2.36 \times 10^{2} \pm 8.34 \times 10^{2} \mathrm{CFU}$ in $1 \mathrm{~g}$ of soil), but in the 
Table 1. Total number of yeast and yeast-like fungi (CFU/g of soil) in samples from children’s recreation areas in Łódź

\begin{tabular}{|c|c|c|c|c|c|c|c|}
\hline \multirow{2}{*}{$\begin{array}{c}\text { Examined sites - } \\
\text { year/season, type } \\
\text { (no. of sites sampled) }\end{array}$} & \multicolumn{7}{|c|}{ Number (average) of yeast $\times 10^{2} \mathrm{CFU} / \mathrm{g}$ of examined sites' soil } \\
\hline & depth & 1 & 2 & 3 & 4 & 5 & 6 \\
\hline \multicolumn{8}{|l|}{ Park playgrounds } \\
\hline \multirow[t]{2}{*}{2010 autumn, UF (4) } & A & 2.60 & 80.00 & 0.20 & 11.20 & * & $*$ \\
\hline & $\mathrm{B}$ & 0 & 3.20 & 0.20 & 1.20 & $*$ & $*$ \\
\hline \multirow[t]{2}{*}{2010 autumn, $\mathrm{F}(3)$} & A & 3.60 & 2.40 & 0.20 & $*$ & * & * \\
\hline & $\mathrm{B}$ & 0 & 0.40 & 0.40 & $*$ & $*$ & $*$ \\
\hline \multirow[t]{2}{*}{2011 spring, UF (4) } & $\mathrm{A}$ & 7.60 & 5.60 & 0.20 & 2.00 & $*$ & $*$ \\
\hline & $\mathrm{B}$ & 0.60 & 1.60 & 0.60 & 1.60 & $*$ & $*$ \\
\hline \multirow[t]{2}{*}{2011 spring, F (3) } & A & 8.80 & 1.80 & 12.00 & $*$ & $*$ & $*$ \\
\hline & $\mathrm{B}$ & 2.80 & 0 & 1.80 & $*$ & $*$ & $*$ \\
\hline \multicolumn{8}{|l|}{ Sandpits } \\
\hline \multirow[t]{2}{*}{2010 autumn, F (6) } & $\mathrm{A}$ & 0 & 0.40 & 0.60 & 0.20 & 0 & 0 \\
\hline & $\mathrm{B}$ & 0 & 0.80 & 0.60 & 0 & 0.20 & 0.60 \\
\hline \multirow[t]{2}{*}{2011 spring, F (6) } & $\mathrm{A}$ & 0.60 & 0 & 0 & 0.40 & 0.40 & 0 \\
\hline & $\mathrm{B}$ & 0.60 & 0 & 0.60 & $\infty$ & 1.60 & 0.40 \\
\hline \multicolumn{8}{|l|}{ School sports fields } \\
\hline \multirow[t]{2}{*}{2010 autumn, PF (5) } & A & 5.40 & 0 & 0.20 & 5.60 & 0.80 & $*$ \\
\hline & $\mathrm{B}$ & 0.40 & 1.20 & 0.60 & 10.40 & 0 & $*$ \\
\hline \multirow[t]{2}{*}{2010 autumn, UF (3) } & A & 0 & 1.80 & 17.60 & $*$ & $*$ & $*$ \\
\hline & B & 0 & 0.80 & 1.60 & $*$ & $*$ & $*$ \\
\hline \multirow[t]{2}{*}{2011 spring, $P F(5)$} & A & 0 & 0 & 0 & 0 & 0 & $*$ \\
\hline & B & 0.20 & 0.20 & 0 & 1.60 & 0 & $*$ \\
\hline \multirow[t]{2}{*}{2011 spring, UF (3) } & $\mathrm{A}$ & 0 & 2.00 & 0.40 & $*$ & * & $*$ \\
\hline & B & 0.20 & 0.60 & 3.20 & * & $*$ & * \\
\hline
\end{tabular}

UF - unfenced; $\mathrm{F}$ - fenced; $\mathrm{PF}$ - partially fenced.

A $-0-3 \mathrm{~cm} ; \mathrm{B}-10-15 \mathrm{~cm}$.

$1-6-$ examined site numbers.

$\mathrm{CFU}$ - colony forming units.

$\infty$ - uncountable growth.

$*$ - not evaluated.

majority of cases they were present in concentrations of up to $1 \times 10^{2} \mathrm{CFU} / \mathrm{g}$ of soil (Table 3). The highest concentrations were discovered for $C$. pelliculosa (once, $80.7 \times 10^{2} \mathrm{CFU} / \mathrm{g}$ of fenced park playground soil superficial layer in autumn), C. laurentii (twice, $11.1 \times 10^{2}$, unfenced park playground soil in autumn and $11.4 \times 10^{2} \mathrm{CFU} / \mathrm{g}$ - school sport field, spring),
C. terreus (twice, $10.3 \times 10^{2}$ and $10.0 \times 10^{2} \mathrm{CFU} / \mathrm{g}$, both from school sport fields, autumn) and $R$. glutinis (three times, $5.54 \times 10^{2}$ and $5.40 \times 10^{2} \mathrm{CFU} / \mathrm{g}$, park playgrounds, spring; $3.67 \times 10^{2} \mathrm{CFU} / \mathrm{g}$, school sport field, autumn). The smallest concentration. $0.13 \times 10^{2} \mathrm{CFU} / \mathrm{g}$, was found for $K$. japonica and in one case, for $C$. laurentii (deep layer, park playground, autumn). 
Table 2. Frequency isolation of fungal species from soil samples of children's recreation areas in Łódź

\begin{tabular}{lccccc}
\hline & $\begin{array}{c}\text { Isolation } \\
\text { Srequency }\end{array}$ & \multicolumn{3}{c}{ Isolation frequency in year, season (\%) } \\
\cline { 3 - 6 } Species & $(\%)$ & all samples) & A & B & 2011 spring \\
\cline { 3 - 6 } & 1.19 & 4.76 & 0 & 0 & B \\
\hline Candida colliculosa & 4.76 & 9.52 & 9.52 & 0 & 0 \\
Candida guilliermondii & 2.38 & 4.76 & 4.76 & 0 & 0 \\
Candida humicola & 1.19 & 4.76 & 0 & 0 & 0 \\
Candida inconspicua & 1.19 & 0 & 4.76 & 0 & 0 \\
Candida lambica & 1.19 & 4.76 & 0 & 0 & 0 \\
Candida lusitaniae & 2.38 & 9.52 & 0 & 0 & 0 \\
Candida pelliculosa & 3.57 & 0 & 9.52 & 0 & 4.76 \\
Candida tropicalis & 8.33 & 9.52 & 9.52 & 14.30 & 0 \\
Cryptococcus albidus & 9.52 & 14.30 & 9.52 & 4.76 & 9.52 \\
Cryptococcus laurentii & 19.00 & 28.60 & 19.00 & 4.76 & 23.80 \\
Cryptococcus neoformans & 8.33 & 9.52 & 9.52 & 4.76 & 9.52 \\
Cryptococcus terreus & 1.19 & 0 & 0 & 0 & 4.76 \\
Kloeckera japonica & 2.38 & 0 & 4.76 & 0 & 4.76 \\
Geotrichum candidum & 5.95 & 9.52 & 9.52 & - & 4.76 \\
Geotrichum penicillatum & 5.95 & 4.76 & 0 & 14.30 & 4.76 \\
Rhodotorula mucilaginosa & 17.90 & 19.00 & 9.52 & 19.00 & 23.80 \\
Rhodotorula glutinis & 1.19 & 0 & 0 & 4.76 & 0 \\
Saccharomyces cerevisiae & 1.19 & 0 & 0 & 4.76 & 0 \\
Sporobolomyces salmonicolor & 16.70 & 14.30 & 19.00 & 9.52 & 23.80 \\
Trichosporon cutaneum & & & & 0 \\
\hline
\end{tabular}

A - depth 0-3 cm; B - depth 10-15 cm.

In sandpits, all isolates were found in numbers below $1 \times 10^{2} \mathrm{CFU} / \mathrm{g}$ of soil, except one: G. candidum from the deeper layer of a fenced sandpit, with documented uncountable growth.

Comparing the fungal species diversity in soils from different children's recreational areas, in sandpits, Cryptococcus, Geotrichum, Rhodotorula and Trichosporon were noticed, without the presence of Candida species (Table 3). The greatest species diversity was observed in park playground soils, where 15 species of 6 genera were identified, while 13 species of 5 genera were detected in the soil of the area around school sports fields.

\section{DISCUSSION}

Yeasts are a constant element of the soil microbial community and play an important role in it; they exert a positive effect on soil structure, nutrient recycling and even plant growth [1,7,11-14]. Some of them are considered autochthonous species, permanently present in soil, while some may be allochthonous, residing transiently or temporarily, and originating from plants, animals or human organisms.

Yeasts are still reported as potential pathogens and a considerable cause of various diseases of humans and animals $[15,16]$. Soil from urban areas, public sites, such as 


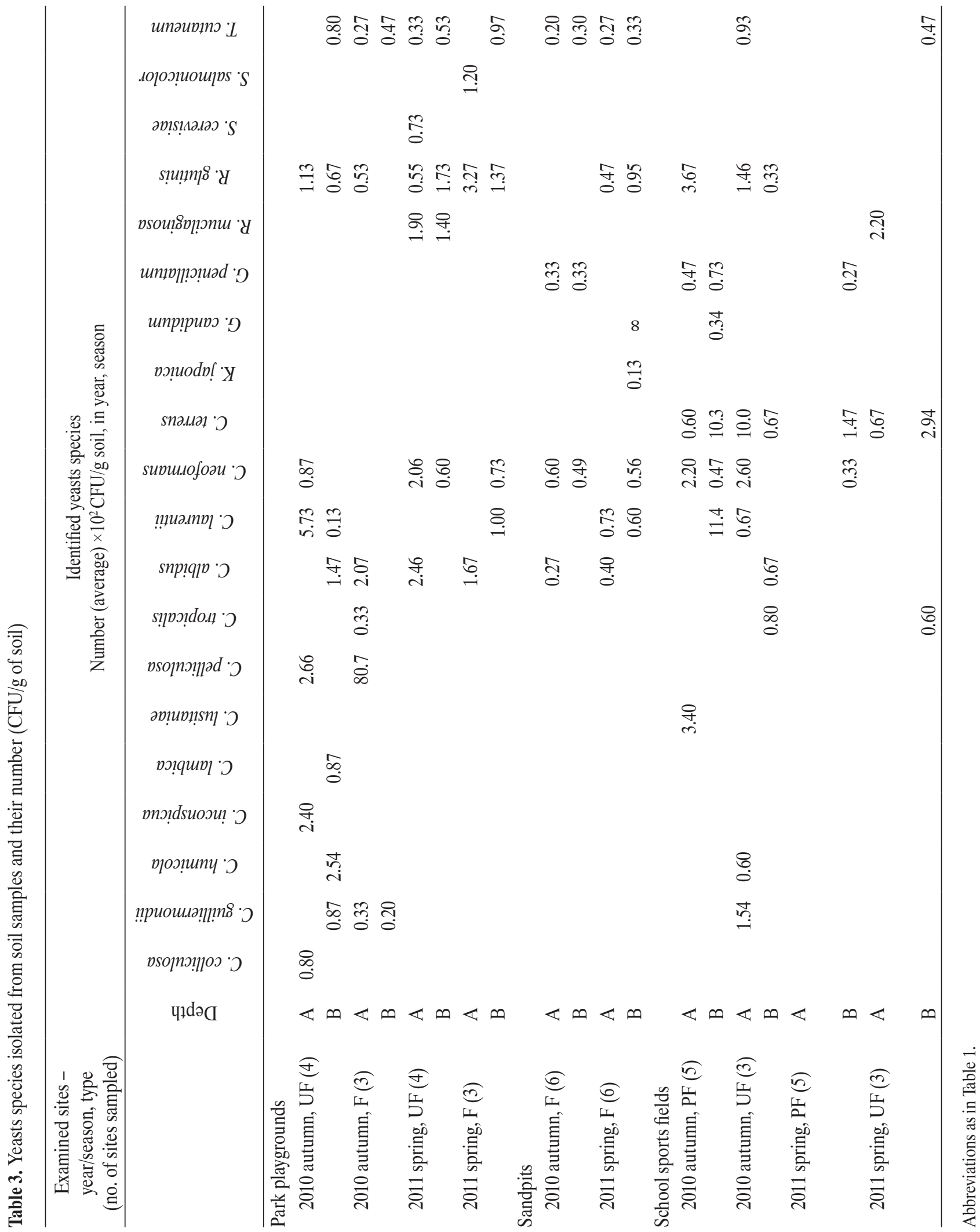


playgrounds, parks, gardens, public squares and sandpits may comprise various yeasts and also receive a considerable dose of the fungi from organisms living above it. The spread of the microorganisms from soil to the human organism is possible; therefore their presence should be regarded as a public health risk.

The total number of soil yeasts observed in different studies varies from 0 to as many as $10^{6} \mathrm{CFU} / \mathrm{g}$ of soil [1]. From natural habitats (deserts, forests, tropical forests, tundra, peat-bogs) at latitudes ranging from $77^{\circ} \mathrm{S}$ to $64^{\circ} \mathrm{N}$, soil yeasts were isolated in numbers from 0.2 to about $10^{4} \mathrm{CFU} / \mathrm{g}$ of soil [11]. Based on 180 soil samples collected in deciduous and coniferous forests, Sláviková and Vadkertiová [12] found the number of yeasts to range from $1.5 \times 10^{3}$ to $1.1 \times 10^{4} \mathrm{CFU} / \mathrm{g}$ soil. During the year, the lowest number of yeasts in forests was ascertained in December and the highest in May. In forests from the European part of Russia, total population concentration of soil yeast was evaluated to be $10^{2} \mathrm{CFU} / \mathrm{g}$ [17]. In tilled soils, the yeast population number ranged from 40 to $6.8 \times 10^{3} \mathrm{CFU} / \mathrm{g}$ soil [4]. For wet and dry sands from South Florida beaches, concentrations of fungi did not demonstrate temporal patterns, and total number varied from $7 \times 10^{2}$ to $3.7 \times 10^{4} \mathrm{CFU} / 100 \mathrm{~g}$ with greater numbers in dry sand [7].

Similar results were found in our studies: the total number of yeast fungi in samples varied from 0 to $8 \times 10^{3} \mathrm{CFU} / \mathrm{g}$ of soil; but an uncountable number of $G$. candidum was detected only in one sample from a kindergarten sandpit in spring. Great diversity was observed in microorganism concentration at all investigated sites without indicating any significant differences in evaluated seasons.

Numerous studies of the yeast composition of soils have revealed great species diversity, but the occurrence of many of them was restricted: they were isolated only from a single site. Vishniac [11] suggests that species which primarily occupy aboveground niches and from which they fall to the soil, usually appear at lower frequencies than yeasts associated with mineral soil. This may be true not only for yeasts colonizing such environments as fruits, cultivated plants and tree leaves, but also yeasts of animal and human organisms. Our investigations revealed 15 isolates of eight Candida species: all discovered in single soil samples from park playgrounds and school sports fields. No C. albicans isolates were identified, but $C$. colliculosa, C. guilliermondii, C. humicola, C. inconspicua, C. lambica, C. lusitaniae, C. pelliculosa and C. tropicalis were found. Literature data from the 1930s reports that the list of cultivable microfungi from various forests, meadows, mountain and agricultural soils of Czech and Slovak Republics includes C. albicans, C. colliculosa, C. lipolytica, C. famata, C. maltosa, C. valida [18].

The Candida species, regarded as the most important group of opportunistic fungal pathogens and most commonly recovered from clinical material, account for 8-10\% of all nosocomial bloodstream infections $[15,16,19]$. The ARTEMIS Global Antifungal Surveillance Program, a 10.5-year evaluation of species distribution of Candida and other opportunistic yeasts, as well as their resistance profiles, showed a decreased rate of isolation of $C$. albicans (70.9\% of all Candida spp. in 1997 to 2000 compared with $65.0 \%$ in the period 2005 to 2007) and increased rates of isolation of the common non-albicans species (e.g. C. tropicalis $-5.4 \%$ to $8.0 \%$ ). The rates of isolation of C. krusei, C. guilliermondii, C. lusitaniae, C. kefyr, and C. famata did not vary significantly, whereas those of fluconazole-resistant species $C$. rugosa, $C$. inconspicua, and C. norvegensis increased 5- to 10 -fold over the 10.5-year study period [20].

It is worth noting that $C$. tropicalis isolates from Taiwan hospitals and soil samples, revealed strains with reduced susceptibility to azole drugs, which can be of great clinical importance [21]. The isolates recovered from humans and soil, originating from different geographic regions of Taiwan, share the same genome pattern (diploid sequence type). This implies that drug resistant fungi exist 
in environments and suggests that soil may be a potential source of these pathogens.

Fungi of the genus Cryptococcus were identified in examined soil environments worldwide, which was attributed to their polysaccharide capsules; they are also frequently isolated in clinical practice [4,5,11,12,17,18,22-24]. Cryptococcus neoformans is the most common species affecting immunocompromised individuals, however, some cryptococcosis cases were also revealed in immunocompetent patients [25-27]. Other species present in soil - C. uniguttulatus, $C$. laurentii and $C$. albidus were previously considered as saprophytes and thought to be non-pathogenic to humans. However, infections caused by those species are now more often observed [28-30].

In the present study, 35 isolates of four Cryptococcus species were found in soil from children's recreational areas. C. neoformans was present in samples collected from park playgrounds, sandpits and school sports fields, and likewise $C$. laurentii and $C$. albidus. The species $C$ terreus was identified only on the school sports fields. The important reservoirs of different fungal species include birds, mainly feral pigeons (Columbia livia), and other bird species often present in towns such as magpies (Pica pica) or house sparrows (Passer domesticus) [31]. The feral pigeon was introduced to Łódź in 1955-1956. At present it can be regularly noted in the city, and in some places in central parts of the city such as the Śródmieście district, which covers only $6.8 \mathrm{~km}^{2}$ but has a population density of 11307 inhabitants $/ \mathrm{km}^{2}$, its concentration exceeds 400 pairs $/ \mathrm{km}^{2}$ [32,33]. Due to the growing problem with pigeon droppings, in May 2009, the City of Łódź Office forbade pigeon feeding in the municipal area: feeding is permitted only in demarcated 26 points of town and on private property. Nevertheless, it is still a sanitary problem, because many citizens enjoy feeding pigeons in parks or places near residential areas and children's playgrounds.

Numerous bird species living on the outskirts can reach the centre of compact cities. Birds make use of the city in the post-nesting period as well. In Łódź, sparrows, magpies, rooks and jackdaws are often observed to be resident throughout the year. Close relations between humans and birds may provoke health problems, as bird faeces can be inhaled as soil dust floating in the air. An example of zoonotic transmission of $C$. neoformans var. grubii from a pet magpie to female patient was suggested in a study in which genetically indistinguishable isolates were cultured from the cerebrospinal fluid of the patient and excreta of the bird [34]. Epidemiological studies of feral pigeon populations from 60 cities and regions revealed that the birds harboured a total of 45 different human pathogenic fungi, among them, twoyeast fungi: C. neoformans, which has been described as routinely transmitted to both immunocompromised and immunocompetent patients, and C. parapsilosis, which is known to be transmitted to the immunocompromised patients [35]. Also, an examination of urban rook (Corvus frugilegus) fecal samples revealed a great number of birds positive for Candida spp. (2.9\%), R. rubra (5.7\% of faecal samples), and for hyphal fungal species [36]. Hence, the cohabitation of birds and humans should be under assessment for potential public health risks.

The evaluations of soil in the present study revealed 18 isolates of two Rhodotorula species, 12 isolates of Trichosporon cutaneum and one of Saccharomyces cerevisiae. The potential human pathogens of the genera Trichosporon, Rhodotorula and Saccharomyces may be colonizers or superficial pathogens (skin or mucosal infections), but all may cause fungemia with or without organ invasion in compromised patients [24]. From clinical specimens, $R$. mucilaginosa (syn. $R$. rubra), $R$. glutinis, and $R$. minuta were obtained; the two first species were also found in our soil samples. Rhodotorula glutinis was the most frequently isolated carotenoids producing species from the leaf surfaces of various tree species and forest soils [12,17,37]. The other species - R. mucilaginosa - belonged to the most frequently encountered yeasts in the sand of bathing beaches in South Florida [7]. The uncommon pathogen, T. cutaneum, has been identified 
in agricultural and forest soils [4,12]; it belongs to the yeast species previously evaluated as the most resistant to various pesticides in agricultural soil [27]. Saccharomyces cerevisiae is widespread in nature - can be found on plants, fruits, in soils; it is a common colonizer of mucosal surfaces, a part of the normal flora of the gastrointestinal tract, respiratory tract, and vagina, but can cause a wide variety of clinical syndromes [24].

In the accessible literature, only a single study concerning soil yeasts from area of children's recreational areas can be found [8]. Soil samples taken from areas subject to intensive student and child use at the University of Ilorin (Nigeria), region of a high desert temperature, registered total fungal colony counts (not only yeasts) ranging between $5.8 \times 10^{2}$ and $1.63 \times 10^{2}$ per $\mathrm{g}$ of soil. Candida albicans, a fungus of great medical importance, was identified with a frequency of $8.5 \%$ in the area around the lecture halls, health centre, and in the playground area used by primary school pupils, which was often littered with food remains. Also G. candidum and S. cerevisiae were found at low frequencies: $11.4 \%$ and $2.8 \%$, respectively.

Some studies have attempted to evaluate the physicochemical soil properties having the greatest impact on yeast fungi populations in their natural habitat. $\mathrm{pH}$ value and divalent cation availability were indicated as the factors for sandy low nutrient soils, while organic carbon and organic nitrogen content influenced nutrient-rich moist soils [1,38]. Another study on the patterns in soil biota, on a large spatial scale and taking into account different land-use types, revealed that yeasts abundance or diversity showed weak relationship with abiotic soil properties [6]. Therefore, it may be concluded that the yeasts in urban soils, their species variety and concentration, may reflect the diversity of organisms: plants growing in and over soil, birds contaminating soil with their faeces and also humans and their activity. The soil may be also the source of health hazards for the organisms living over it, and it may be the element of potentially pathogenic fungi transmission to humans, especially children. Further studies are required to determine the possible correlation of yeast populations in recreational areas and the potential associated health risks for children.

\section{CONCLUSIONS}

Potentially pathogenic yeasts were identified in the soil of children`s recreational areas in parks, schools and kindergartens. They persist at concentrations which are not very high, but the diversity of species is considerable. Isolates of the Candida, Cryptococcus, Kloeckera, Geotrichum, Rhodotorula, Saccharomyces, Sporobolomyces and Trichosporon genera were identified. Their presence in the environment may pose a health risk to humans, especially to children. This type of biological pollution should be regarded as a potential public health risk.

\section{REFERENCES}

1. Botha A. The importance and ecology of yeasts in soil. Soil Biol Biochem 2011;43(1):1-8. DOI: 10.1016/j.soilbio.2010.10.001.

2. Yurkov AM, Kemler M, Begerow D. Assessment of yeast diversity in soils under different management regimes. Fungi and Global Change. Fungal Ecol 2012;5(1):24-35. DOI: 10.1016/ j.funeco.2011.07.004.

3. Wuczkowski M, Prillinger H. Molecular identification of yeasts from soils of the alluvial forest national park along the river Danube downstream of Vienna, Austria ("Nationalpark Donau-Auen”). Microbiol Res 2004;159(3):263-75. DOI: 10.1016/ j.micres.2004.05.001.

4. Sláviková E, Vadkertiová R. The diversity of yeasts in agricultural soil. J Basic Microbiol 2003;43(5):430-36. DOI: 10.1002/ jobm.200310277.

5. Wuczkowski M, Sterflinger K, Kraus GF, Klug B, Prillinger H. Diversity of microfungi and yeasts in soils of the alluvial zone national park along the river Danube downstream of Vienna, Austria ("Nationalpark Donau-Auen"). Bodenkultur 2003;54(2):109-17. 
6. Birkhofer K, Schöning I, Alt F, Herold N, Klarner B, Maraun M, et al. General relationships between abiotic soil properties and soil biota across spatial scales and different land-use types. PLoS ONE 2012;7(8):e43292. DOI: 10.1371/journal. pone. 0043292 .

7. Vogel C, Rogerson A, Schatz S, Laubach H, Tallman A, Fell J. Prevalence of yeasts in beach sand at three bathing beaches in South Florida. Water Res 2007;41(9):1915-20. DOI: 10.1016/j.watres.2007.02.010.

8. Durowade KA, Kolawole OM, Uddin II RO, Enonbun KI. Isolation of Ascomycetous Fungi from a Tertiary Institution Campus Soil. J Appl Sci Environ Manage 2008;12(4):57-61.

9. Kurnatowska A., Kurnatowski P. Mikologia medyczna. Łódź: Promedi; 2006.

10. De Hoog GS, Guarro J, Gene J, Figueras MJ. Atlas of clinical fungi. Centraalbureau voor Schimmelcultures. Utrecht: University Rovira and Virgili, Rens; 2000.

11. Vishniac HS. A Multivariate Analysis of Soil Yeasts Isolated From A Latitudinal Gradient. Microb Ecol 2006;52:90-103. DOI: 10.1007/s00248-006-9066-4.

12. Sláviková E, Vadkertiová R. The occurrence of yeasts in the forest soils. J Basic Microbiol 2000;40(3): 207-12. DOI: 10.1002/1521-4028(200007)40:3<207::AIDJOBM207>3.0.CO;2-H.

13. Lisichkina GA, Bab'eva IP, Sorokin DYu. Alkalitolerant yeasts from natural biotopes. Microbiology 2003;72(5):61820. DOI: 10.1023/A:1026011821021.

14. Boby VU, Balakrishna AN, Bagaraj DJ. Interaction between Glomus mossae and soil yeasts on growth and nutrition of cowpea. Microbiol Res 2006;163(6):693-700. DOI: 10.1016/j.micres.2006.10.004.

15. Pfaller MA, Diekema DJ. Epidemiology of Invasive Candidiasis: A Persistent Public Health Problem. Clin Microbiol Rev 2007;20(1):133-63. DOI: 10.1128/CMR.00029-06.

16. Enoch DA, Ludlam HA, Brown NM. Invasive fungal infections: A review of epidemiology and management options. J Med Microbiol 2006;55(7):809-18. DOI: 10.1099/ jmm.0.46548-0.
17. Maksimova IA, Chernov IYu. Community structure of yeast fungi in forest biogeocenosis. Microbiology 2004;73(4):47481. DOI: 10.1023/B:MICI.0000036994.21650.3a.

18. Nováková A, Šimonovičová A, Kubátová A. List of cultivable microfungi recorded from soils, soil related substrates and underground environment of the Czech and Slovak Republics [cited 2013 Jan 15]. Mycotaxon 2012;119:593. Available from URL: http://www.mycotaxon.com/resources/checklists/ Novakova-v119-checklist.pdf.

19. Pfaller MA, Pappas PG, Wingard JR. Invasive fungal pathogens: Current epidemiological trends. Clin Infect Dis 2006;43:S3-14. DOI: 10.1086/504490.

20. Pfaller MA, Diekema DJ, Gibbs DL, Newell VA, Ellis D, Tullio V, et al. Results from the ARTEMIS DISK Global Antifungal Surveillance Study, 1997 to 2007: A 10.5-year analysis of susceptibilities of Candida Species to fluconazole and voriconazole as determined by CLSI standardized disk diffusion. J Clin Microbiol 2010;48(4):1366-77. DOI: 10.1128/JCM.02117-09.

21. Yang Y-L, Lin C-C, Chang T-P, Lauderdale T-L, Chen H-T, Lee CF, et al. Comparison of human and soil Candida tropicalis isolates with reduced susceptibility to fluconazole. PLoS ONE2012;7(4):e34609. DOI:10.1371/journal.pone.0034609.

22. Yurkov AM, Kemler M, Begerow D. Species accumulation curves and incidence-based species richness estimators to appraise the diversity of cultivable yeasts from beech forest soils. PLoS ONE 2011;6(8):e23671. DOI: 10.1371/journal. pone.0023671.

23. Saleh HA, Moawad AA, El-Hariri M, Refai MK. Prevalence of yeasts in human, animals and soil sample at El-Fayoum Governorate in Egypt. Int J Microbiol Res 2011;2(3):233-9.

24. Pfaller MA, Diekema DJ. Epidemiology of Invasive Mycoses in North America. Crit Rev Microbiol 2010;36(1):1-53. DOI: 10.3109/10408410903241444.

25. Yuge S, Bastazini Júnior I, Coelho MC, Soares CT. Cutaneous cryptococcosis in an immunocompetent host. Acta Derm Venereol 2006;86(2):165-6. DOI: 10.2340/00015555-0021.

26. Gupta P, Malik S, Khare V, Banerjee G, Mehrotra A, Mehrotra S, et al. A fatal case of meningitis caused by Cryptococcus 
neoformans var. grubii in an immunocompetent male. J Infect Dev Ctries 2011;5(1):71-4.

27. Sláviková E, Vadkertiová R. Effects of pesticides on yeasts isolated from agricultural soil. Z Naturforsch 2003;58c:855-9.

28. Cheng MF, Chiou CC, Liu YC, Wang HZ, Hsieh KS. Cryptococcus laurentii fungemia in a premature neonate. J Clin Microbiol 2001;39:1608-11. DOI: 10.1128/JCM.39.4.16081611.2001.

29. Furman-Kuklińska K, Naumnik B, Myśliwiec M. Fungaemia due to Cryptococcus laurentii as a complication of immunosuppressive therapy - A case report. Adv Med Sci 2009;54(1):1169. DOI: 10.2478/v10039-009-0014-7.

30. Khawcharoenporn T, Apisarnthanarak A, Mundy LM. Nonneoformans cryptococcal infections: A systematic review. Infection 2007;35(2):51-8. DOI: 10.1007/s15010-007-6142-8.

31. Rosario I, Acosta B, Colom F. Pigeons and other birds as a reservoir for Cryptococcus spp. Rev Iberoam Micol 2008;25:S138 [in Spanish].

32. Markowski J, Wojciechowski Z, Kowalczyk JK, Tranda E, Śliwiński Z, Soszyński B. Fauna of Lodz. Lódź: Fundacja „Człowiek i Środowisko”; 1998 [in Polish].

33. Markowski J, Kowalczyk JK, Janiszewski T, Wojciechowski Z, Szczepko K, Domański J. Fauna of Lodz - State of knowledge, changes, protected and threatened species. In: Indykiewicz P., Barczak T. [red.]. Fauna of 21st Century Central Europe Towns. Bydgoszcz: Wydawnictwo LOGO; 2004. p. 19-36 [in Polish].

34. Lagrou K, Van Eldere J, Keuleers S, Hagen F, Merckx R, Verhaegen J, et. al. Zoonotic transmission of Cryptococcus neoformans from a magpie to an immunocompetent patient. J Intern Med 2005;257:385-8. DOI: 10.1111/j.13652796.2005.01466.x.

35. Haag-Wackernagela D, Moch H. Health hazards posed by feral pigeons. J Infect 2004;48:307-13. DOI: 10.1016/j. jinf.2003.11.001.

36. Vlahović K, Prukner-Radovčić E, Horvatek D, Pavlak M, Gomerčić T, Rumiha Z, et al. Bacterial and fungal flora in faecal samples from rooks (Corvus frugilegus) in the City of Zagreb, Croatia. Vet Arh 2010;80:81-92.

37. Sláviková E, Vadkertiová R, Vránová D. Yeasts colonizing the leaf surfaces. J Basic Microbiol 2007;47:344-50. DOI: 10.1002/jobm.200710310.

38. Vreulink J, Esterhuyse A, Jacobs K, Botha A. Soil properties that impact yeasts and actinomycete numbers in sandy low nutrient soils. Can J Microbiol 2007;53:1369-74. DOI: 10.1139/ W07-092.

This work is available in Open Access model and licensed under a Creative Commons Attribution-NonCommercial 3.0 Poland License - http://creativecommons.org/ licenses/by-nc/3.0/pl/deed.en. 